\title{
Bolotnajarörelsen: politisk kultur, identitet och mobilisering
}

\begin{abstract}
Aleksej Sachnin
SAMMANDRAG: I december 2OII drogs världens uppmärksamhet mot ett parlamentsval i Ryssland som kantades av omfattande anklagelser om valfusk och genererade en protestvåg som vi inte sett i landet sedan 1990-talet. Konsekvenserna av "rörelsen för rättvisa val" (också kallad Bolotnajarörelsen och snörevolutionen) blev djupgående för det ryska samhället trots att protesterna 20II-2OI2 inte ledde till den eftersträvade demokratiseringen av det politiska systemet. Aleksej Sachnins artikel utforskar formerna för och mekanismerna bakom massmobiliseringen runt Bolotnajarörelsen, dess sociala bas och kollektiva identitet. Sachnin visar att oppositionella eliter såväl som eliter lojala med makten gjorde försök att integrera rörelsen i sin populistiska agenda. Samtidigt demonstrerade rörelsen en enorm potential för gräsrotsaktivism med dess horisontella organisationsstrukturer och orientering mot målinriktade (och ofta pragmatiska) aktivitetsformer. Rörelsens mångfald gav utrymme för framväxten av olika former av kollektiva identiteter vilket till slut blev dess avgörande svaghet.
\end{abstract}

NYCKELORD: Ryssland; rörelsen för rättvisa val; Bolotnajarörelsen; snörevolutionen; social mobilisering; politisk kultur; kollektiv identitet; kollektiv handling.

PUBLICERINGSHISTORIK: Originalpublicering.

ALEKSEJ SACHNIN är fil.dr i historia vid Statliga akademiska universitetet av humaniora i Moskva.

E-POSTADRESs: asakhnin@gmail.com

FÖRSLAG PÅ KÄLLANGIVELSE:

Sachnin, Aleksej (20I7) "Bolotnajarörelsen: politisk kultur, identitet och mobilisering", i Från perestrojka till Bolotnaja. Utvecklingen av ett ryskt civilsambälle, specialnummer av Arkiv. Tidskrift för sambällsanalys, nr 7, s. 93-I27.

DOI: https://doi.org/IO.I3068/2000-6217.7.3

(C) Aleksej Sachnin/Arkiv förlag \& tidskrift 2017 (publicerad 8 februari 20I7)

Artikeln distribueras enligt en upphovsrättslicens från Creative Commons:

Erkännande-Ickekommersiell-IngaBearbetningar 3.o Unported, som medger fri ickekommersiell användning och spridning i oförändrat skick så länge källan anges. 
Arkiv. Tidskrift för samhällsanalys är en sakkunniggranskad vetenskaplig tidskrift för samhällsvetenskap och historia. Samtliga artiklar publiceras fritt tillgängliga på:

$$
\text { www.tidskriftenarkiv.se }
$$

Beständig länk, DOI: https://doi.org/IO.I3068/2000-62I7

Den här artikeln finns tillgänglig i följande format:

PDF \& HTML: via beständig länk, DOI: https://doi.org/IO.I3068/2000-62I7.7.3

EPUB: ingår i e-boksutgåva av numret, ISBN: 978 9I 7924283 I

TRYCK: ingår i bokutgåva av numret, ISBN: 978 9I 79242848

Grafisk utformning och sidnumrering är identisk i pdf och tryck.

Samtliga artiklar i nr 7 (20I7), Från perestrojka till Bolotnaja. Utvecklingen av ett ryskt civilsamhälle, nås via beständig länk, DoI: https://doi.org/IO.I3068/2000-6217.7

REDAKTÖR FÖR NUMRET: Zhanna Kravchenko

Arkiv. Tidskrift för samhällsanalys ISSN: 2000-62I7 (för elektronisk resurs)

ISSN: 2000-6225 (för tryckta nummer)

ges ut av

Stiftelsen Arkiv för främjande och spridning av samhällsvetenskaplig och historisk forskning

genom

Arkiv förlag \& tidskrift

Box 1559

SE-22I OI Lund

ВESÖK: L Gråbrödersg 3 c, ipg

TEL: 046-I3 3920

ARKIV FÖRLAG: arkiv@arkiv.nu·www.arkiv.nu

TIDSKRIFTEN ARKIV: red@tidskriftenarkiv.se · www.tidskriftenarkiv.se

ANSVARIg UTGIVARE \& CHEFREDAKTÖR: Sven Hort

ADMinistrativ RedAKTÖr: David Lindberg

ReDAKTörer: Paavo Bergman, Lisa Kings, Zhanna Kravchenko 


\title{
Bolotnajarörelsen: politisk kultur, identitet och mobilisering
}

\author{
ALEKSEJ SACHNIN
}

Ett av exemplen på de nya massproteströrelserna i Ryssland är den så kallade Bolotnajarörelsen 2OII-20I2 som blivit den allvarligaste sociopolitiska omvälvningen i landet på många år. En undersökning av den erfarenheten gör det möjligt att placera in detta fenomen i en rad av likartade rörelser från hela världen under samma tid, med sin början i den arabiska våren och sitt slut i Occupy Wall Street, liksom att komma närmare en förståelse av den logik som styr den sociala kampens dynamik i dagens globaliserade värld.

I denna artikel uppställer jag en rad mål: att beskriva massproteströrelsens utveckling under perioden 2OII-20I2, att identifiera grunddragen i de typer av politisk kultur som fick sina former inom ramarna för denna rörelse, liksom att analysera de avgörande dilemman som den konfronterades med under sitt utvecklingsförlopp. Hit hör problemen med samverkan mellan rörelsen och den traditionella eliten, men också de former som denna samverkan antog; det ideologiska sökandet och proteströrelsens former av diskursiv kultur, men också de begränsningar som dessa former uppreser för rörelsens utveckling; utvecklingen av former och teknologier för mobilisering; rörelsens sociala natur och dess kollektiva identitet. 


\section{"Snörevolutionen". En historieteckning}

Proteströrelsen i Moskva 20II-20I2 kom att redan från början bli förknippad med Bolotnajatorget i huvudstadens centrum. Just där tilldrog sig de tre viktigaste händelserna i dess historia - protestmötena och demonstrationerna den Io december 20II, 4 februari och 6 maj 2012. Därför har den, i såväl press som historiemedvetande, blivit ihågkommen

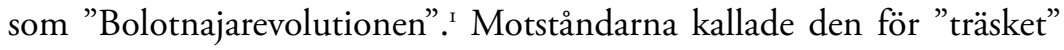
(bolotnoje betyder "det som är beläget i ett träsk" på ryska). Med tiden har många aktivister gjort denna nedvärderande stämpling till sin, som en egen benämning på rörelsen. Termen "rörelse" kommer att användas i två bemärkelser i denna text. För det första, i den vidaste bemärkelse, som en form av kollektiv handling i offentligheten. Just i denna kontext bör man förstå hur den används med tillämpning på hela kampanjens historia 20II-20I2. För det andra kommer termen att tillämpas på en rad organisationer eller aktivistnätverk, till exempel "Vänsterfronten" (Levyj front) och "Solidaritet" (Solidarnost'), i den bemärkelse som den har i den ryska lagstiftningen: sociopolitiska massorganisationer som saknar partiregistrering och tydlig struktur.

Parlamentsvalen den 4 december 201 blev den avtryckarmekanism som utlöste de första massprotesterna och som i sig definierade de protesterandes huvudkrav. Enligt deltagarna i rörelsen (liksom i något lägre grad de några tusen personer som fungerade som frivilliga valobservatörer i vallokalerna) manipulerade myndigheterna grovt dessa val för att tillförsäkra det regeringstrogna partiet Enade Ryssland (Edinaja Rossija) den formella segern. Valen 20II skiljer sig för övrigt föga från flertalet föregående regionala och nationella omröstningar, i vilka myndigheterna ofta tillgripit såväl manipulationer som den så kallade administrativa resursen. Men några till omfattningen jämförbara manifestationer hade inte ägt rum i det postsovjetiska Ryssland.

Massdemonstrationerna föregicks av en tämligen intensiv kampanj av kritik mot myndigheterna och deras förvalsmanipulationer i oppositionella medier och sociala nätverk - med en publik som åtminstone

I. I engelskspråkiga medier omtalades protesterna också som "snörevolutionen”. Red. anm. 
uppgick till flera hundra tusen människor. Omfattningen på de första protestaktionerna visade sig dock vara fullständigt oväntade för flertalet oppositionella, journalister och analytiker. Tiotusentals människor gick ut på gatorna med krav på att de officiella resultaten av parlamentsvalen skulle upphävas och att en ny omröstning skulle genomföras, eller att rösterna åtminstone skulle räknas om. Därför kan man säga att den första egna benämningen på rörelsen var "rörelsen för rättvisa val". Den politiska protestagendan skulle dock successivt vidgas och få en mer radikalt antiputinsk anstrykning. Detta tog sig uttryck i att tonvikten i slagorden och stämningarna bland demonstranterna successivt försköts från behovet att "räkna om rösterna” eller "organisera nya parlamentsval" till krav på att Putin skulle avgå och den auktoritära regimen avvecklas (och inte reformeras).

Mycket snart uppkom en egenartad koalition som inbegrep företrädare för olika politiska partier och grupper, samhällsrörelser, kända journalister, skribenter och så vidare, och som strävade efter att bli den framväxande rörelsens organisatoriska centrum. Dess arbetsorgan genomgick under protestårets lopp en evolution från "Organisationskommittén", med närmast slumpmässiga företrädare, till "Samordningsrådet för den ryska oppositionen", vars sammansättning fastställdes genom resultatet av en omröstning bland proteströrelsens anhängare. Samtidigt som denna framträdde också en annan struktur vilken inledningsvis som egenbenämning antog namnet "Medborgarkommittén" (en annan benämning var "Initiativgruppen") och som utgjorde ett öppet forum för aktivistgrupperna, från extremvänster till extremhöger, och från människorättskämpar till miljöaktivister. Den blev också en plattform för oppositionsanhängarnas offentliga diskussion och spelade en stor roll för tillblivelsen, självorganisationen och formerandet av proteströrelsens politiska dagordning (Sachnin 20I4).

Under vintern 20II-20I2 genomfördes fyra betydande massprotestaktioner i Moskva. Likartade aktioner (om än mindre till storleken) genomfördes i Sankt Petersburg, Novosibirsk och många andra städer. Dessutom genomfördes hundratals andra gatuaktioner, konferenser, rundabordssamtal, konstprojekt och så vidare, som organiserades av rörelsens aktiva deltagare och som hade en direktkoppling till dess dag- 
ordning. Enligt uppskattningar av oberoende journalister och analytiker deltog uppemot Ioo ooo eller till och med fler personer i protestdemonstrationerna bara i Moskva. ${ }^{2}$ De mer betydande protestmötena i landsorten samlade omkring 7 0oo-Io ooo demonstranter. Det är svårare att uppskatta det antal människor som utgjorde rörelsens aktivistiska kärna, det vill säga de som inte bara kom till de mer omfattande protestmötena, utan också deltog i agitatorisk, organisatorisk och liknande verksamhet. Men det kan i varje fall röra sig om tusentals eller till och med tiotusentals personer. De mest populära oppositionsledarna bland deltagarna i protesterna i december 20 II var bloggaren och antikorruptionskämpen Aleksej Navalnyj, den liberala politikern Grigorij Javlinskij och oligarken Michail Prochorov. Prochorovs och den alltför moderate Javlinskijs auktoritet sjönk dock gradvis och till september 2012 hade de strukits från listan över de moraliska och politiska auktoriteterna. Vid samma tidpunkt blev en av rörelsens karismatiska ledare, Sergej Udaltsov, successivt ledare för den radikala Vänsterfronten.

De opinionsundersökningar som genomfördes bland deltagarna i protestmötena under loppet av de följande månaderna vittnar om att grundtendensen i proteströrelsens utveckling var en tämligen rask radikalisering. Andelen rika och framgångsrika medborgare i proteströrelsen minskade drastiskt. Förespråkarna av liberala värderingar och åsikter blev färre, och anhängarna av vänsteridéer, vänsterradikala och nationalistiska idéer blev, tvärtom, allt fler för varje ny aktion (LevadaCentr 20I2). Förklaringen till detta ligger i de erfarenheter rörelsen gjorde och de två vändpunkter den genomlevde under sitt utvecklingsförlopp.

Den första vändpunkten var det presidentval som ägde rum den 4 mars 2012 och i vilket Vladimir Putin tog hem en förutsägbar seger. En del av de politiker och företrädare för den ryska eliten, som tidigare varit anhängare av eller åtminstone sympatiserat med proteströrelsen, distanserade sig från eller förlorade intresset för den efter det. Oppositionens kandidater till presidentposten, som en betydande del av de proteste-

2. Polisen gav uppenbart förminskande uppskattningar av antalet protestdeltagare: 25 000-29 000. Organisatörerna själva är benägna att åberopa några överdrivna uppgifter: uppemot 150 ooo på protestmötet den 24 december $201 \mathrm{I}$. 
rande satte stort hopp till, erkände sin förlust och försvann praktiskt taget från offentligheten. Deras lojalitet med Kreml stötte bort många av anhängarna.

Mediebevakningen av proteströrelsen upphörde också och under halvannan månad i mars-april 2012 ägde inga större protestaktioner rum i huvudstaden. I massmedia framträdde ett nytt fast motiv: protesten var på tillbakagång. Men samtidigt som de ledare och den del av aktivisterna som var inställda på att kompromissa med det rådande etablissemanget lämnade proteströrelsen, påbörjades en energisk konsolidering av de aktivister som helt enkelt inte var beredda att återgå till en kälkborgerlig apolitisk hållning, och ville se en fortsättning på protestkampanjen. Efter att ha blivit av med stödet från de medielanserade politikerna och ledarna, som dittills definierat protestaktionens dynamik, började de själva söka vägar för sitt medborgerliga förverkligande.

Om proteströrelsen under vintern 2OII-2OI2 hade varit koncentrerad på större massaktioner i Moskva (och, i lägre grad, i regionerna), så decentraliserades de efter presidentvalet och föll sönder i en mängd självständiga strömningar. Den autonomi från de statusladdade politikerna som därmed uppkom möjliggjorde en ökning av aktivisternas egenorganisering. Det är möjligt att det var just frånvaron av dialog med makten och besvikelsen på de systemoppositionella politikerna som eldade på denna stämning av radikalisering. Några rörelser upplevde ett tillflöde av aktivister. Aktivistförbunden (i stället för de offentliga politikerna och mediestjärnorna) förvandlades till en huvuddrivkraft för kampanjerna, och den huvudsakliga stämningen inom rörelsen rörde sig mot radikalism och nonkonformism i förhållande till makten. I denna jordmån växte drastiskt auktoriteten och inflytandet för de krafter och ledare som i det allmänna medvetandet var förknippade just med proteströrelsens radikala falang. Detta gällde exempelvis i mycket hög grad just Vänsterfronten och de andra ideologiska grupperna, och kom till starkt uttryck i den växande populariteten för Udaltsov, som ansågs vara den mest radikala bland de politiker och ledare som deltog i protestkampanjen.

Samtidigt uppstod ett stort antal autonoma och vanligtvis ickeideologiska initiativ i stil med gruppen "Motstånd" (Soprotivlenije) vil- 
ken ska diskuteras mer längre fram. En mobilisering genom medierna fick successivt ge vika för en mobilisering genom gemensamma kollektiva praktiker. Detta tog sig särskilt tydligt uttryck i protestaktioner som kampanjen mot uthuggningen av skogen i Zjukovskij i närheten av Moskva. Sammantaget tiotusentals aktivister deltog i liknande initiativ i Moskva och i regionerna.

Den andra vändpunkten i demokratirörelsens historia 20II-20I2 var den dramatiska demonstrationen i Moskva den 6 maj 20I2. Till denna demonstration, som framprovocerats av att Putin skulle sväras in som president, kom, trots aktivisternas och organisatörernas pessimistiska förväntningar, praktiskt taget lika många människor som till de större protestmötena under vintern. Bland de som protesterade denna gång fanns exempellöst många människor från regionerna. Aktivisterna från Sankt Petersburg, Astrachan och Zjukovskij formerade egna kolonner. De egenhändigt förfärdigade plakat som höjdes ovanför huvudena vittnade om närvaron av aktivister från Murmansk, Nizjnij Novgorod, Omsk, Samara, Barnaul och till och med Petropavlovsk-Kamtjatskij.

När demonstranterna satte sig i rörelse stod det klart att de röda färgerna dominerade därute. Inte mindre än hälften av de som kommit anslöt sig till vänsterkrafternas kolonn. Så gjorde också en majoritet av de sociala aktivisterna - från "Moskvauniversitetets initiativgrupp" (Iniciativnaja gruppa MGU) till en rörelse av medinvesterare och lurade andelsägare. Med vänstern gick också en kolonn till försvar för gruppen Pussy Riot. Journalister noterade att det bland de slagord som skanderades av de som hade ansamlats rådde en övervikt för de uttalat vänsterpolitiska: "Framåt, framåt, framåt arbetarklass!" (Feldman 20I2).

Till mångas förvåning var protestens öppna vänstervridning inte det enda, inte ens det huvudsakliga resultatet av demonstrationen den 6 maj. Stick i stäv med den överenskommelse som uppnåtts mellan talespersonerna för aktionen och stadsförvaltningen, blockerade myndigheterna nästan fullständigt tillträdet till Bolotnajatorget och lämnade bara några metalldetektorsbågar att passera in igenom. För att undvika trängsel hejdade organisatörerna kolonnernas rörelse. Men ganska snart provocerade polisen fram en riktigt skarp sammandrabbning mellan sig och demonstranterna vilket resulterade $\mathrm{i}$ att ett hundratal människor 
misshandlades, ett hundratal arresterades, och själva demonstrationen upplöstes (Sachnin 20I4).

Maktens godtycke provocerade fram ett nytt uppsving för proteststämningarna. Under loppet av maj 2012 ägde protestaktioner rum så gott som dagligen i Moskva. I huvudstadens centrum restes ett fast oppositionellt fältläger, som blev känt som "Occupy Abaj”, eftersom det bredde ut sig kring poeten Abaj Kunanbajevs staty på Čistoprudnyjboulevarden. Där uppehöll sig I ooo till 2 ooo människor varje dag under loppet av två veckor, men under helgerna och i stunder av större spontana aktioner så uppgick detta antal till flera tusen människor. Här pågick nästan oavbrutet konferenser, konstpresentationer och diskussioner. Lägrets demokratiska självstyrelseinstitution - Assemblén - fungerade, och i den dryftade man rörelsens taktiska och strategiska frågor.

Från slutet av maj inleddes repressioner mot proteströrelsens aktivister och dessa åtföljdes av en propagandakampanj på statstelevisionen. I synnerhet i filmen Anatomija protesta-2 ("Protestens anatomi 2"), som sändes på tevekanalen NTV, anklagade man oppositionsledarna för att ägna sig åt att spionera för utlandet och för landsförräderi. Men proteströrelsen bibehöll en viss tid sin förmåga att mobilisera. Större oppositionsaktioner ägde rum under sommaren och hösten 20I2, och till och med under vintern 20I3. Dock växte meningsskiljaktigheterna kring taktik och strategi mellan oppositionsledarna och proteströrelsens olika ideologiska falanger. Situationen förbättrades inte (men försämrades kanske inte heller) av de val till Samordningsrådet för den ryska oppositionen som organiserades i oktober 2012 i vilka fler än åttiotusen röstande deltog. Det organ som åstadkoms visade sig vara handlingsoförmöget och dess låga aktivitet ledde till att det snart diskrediterades.

Resultatet blev att massproteströrelsen försvann under vintern 20122013. Flertalet aktivister övergick från angrepps- till försvarshandlingar. Det rörde sig i första hand om en övergång till människorättsverksamhet, i synnerhet inom ramen för en kampanj för frisläppandet av aktivister som fängslats i samband med demonstrationen den 6 maj. I det emotionella uppsvingets ställe kom nedslagenhet och demoralisering. Svaren i opinionsundersökningarnas frågeformulär vittnar om att antalet människor som hade börjat fundera på att emigrera drastiskt växte i hela landet, 
och i synnerhet i de större storstäderna. På politikens område etablerade sig en regim av tämligen djupgående reaktionärt slag, som åtföljdes av repressioner, antagande av antidemokratiska lagar och påtryckningar på massmedia och icke-statliga organisationer. Den demokratiska rörelsen led ett nederlag i kamp mot den auktoritära regimen.

\section{Bolotnajarörelsens inre drivkrafter. Ett sociologiskt analysförsök}

Man kan bara förstå massproteströrelsens kris genom att identifiera dess avgörande dilemman och de beslut som betingade rörelsens utveckling. Jag ska här i ordningsföljd undersöka mekanismen och karaktären hos den mobilisering som var utmärkande för Bolotnajarörelsen, den sociala naturen för de former av identitet som kom till uttryck under dess utvecklingsförlopp och de diskursiva praktikerna och det ideologiska sökandet, men också förbindelserna mellan rörelsen och den ekonomiska och politiska eliten och de former genom vilka dessa förbindelser institutionaliserades. På grundval av detta kommer det bli möjligt att dra slutsatser om vilka typer av politisk kultur som dominerade inom proteströrelsen, vilka grupper som framträdde som bärare av dessa kulturer och hur detta avspeglade sig på rörelsens utveckling som helhet.

\section{Mobiliseringens särdrag}

Mobilisering av sociala grupper kan formeras vertikalt, exempelvis med stöd av medier, eller horisontalt, genom mer eller mindre organiserade aktivistnätverk. Detta är avgörande för såväl rörelsens potential och förmåga att inkludera nya sociala grupper som dess grad av oavhängighet av yttre krafter (ägare av massmedier, staten, politiker). I spåren av jasminrevolutionen i Tunisien och händelserna på Tahrirtorget i Kairo 20II, var Bolotnajarörelsen i såväl det allmänna medvetandet som i massmedierna fast förknippad med sociala medier, särskilt med Facebook, VKontakte och Twitter. Sådana bedömningar kablades ut i etablerade medier och plockades därifrån upp av många aktivister. Även en del forskare såg internetteknologiernas roll som absolut och som grunden för en ny typ 
av massmobilisering och social samverkan inom rörelsen (Lonkila 20I2; Sokolov 2012).

Sociala nätverk och bloggar blev verkligen en ytterst viktig plattform där rörelsens aktivister och dess ledare samverkade. De tjänade också mobiliseringssyften. Och det var, vid en första anblick, mycket effektivt. Inför protestmötet på Sacharovavenyn den 24 december 2011 gick exempelvis 54000 personer med bara i mobiliseringsgruppen på Facebook. Och två av de mest populära svarsvarianterna på frågan "Varifrån fick ni kännedom om dagens protestmöte?", som Levadacentret ställde till de intervjuade denna dag, var "internetpublikationer" ( 56 procent) och "andra källor på internet" (33 procent) (Levada-Centr 20II). Men redan efter lite drygt en månad, inför demonstrationen den 4 februari 2012 (till vilken ett fullt jämförbart antal deltagare gjorde sig redo), skrev bara 28 ooo deltagare in sig i en likartad Facebookgrupp. Och inför den 6 maj 2012 var det allt som allt bara 8 ooo anmälda Facebook-aktivister. Ett liknande fenomen kunde iakttas också i det andra mycket omfattande sociala nätverket, VKontakte. Kopplingen mellan källorna för den inhämtade informationen och mobiliseringens särdrag visade sig på så vis vara väsentligt mindre uppenbar.

Den finska sociologen Markku Lonkila (20I2) antar att sociala nätverk ur massmobiliseringssynvinkel också kvalitativt skiljer sig från traditionella massmedier. Han har formulerat denna skillnad i form av oppositioner mellan kommunikation av typen "en till många" (one-tomany) och "många till många" (many-to-many). Men i verkligheten var denna skillnad alldeles illusorisk. Konton på sociala medier som hade tioeller till och med hundratusentals prenumeranter, sådana som Aleksej Navalnyjs, Maksim Katz eller Ilja Jasjins bloggar, fyllde funktionen av huvudsakliga noder för informationsförmedling och mobilisering. Det vill säga att de reproducerade precis den traditionella meddelande- och mobiliseringsmodell som karakteriserar vanliga massmedier. I denna bemärkelse drar den ryska sociologen Soboleva rättvist slutsatsen att de sociala nätverken och "offentliga medier ger 'verbala halvfabrikat', färdiga värderingspositioner och hjälper till att artikulera en ståndpunkt under förhållanden av en outvecklad offentlighet”, och skiljer sig på detta vis lite från traditionella masskommunikationsverktyg (Soboleva 20I3). Det 
råder ingen tvekan om att dessa verktygs roll var ytterst stor under de första dagarna och veckorna i rörelsens utveckling. Lonkila har rätt i att "de ryskspråkiga sociala medierna fram till valet växte ut till en alternativ offentlighet som ersatte de stereotypa rapporterna på den nationella statstelevisionen. Denna offentlighet ackumulerade det groende missnöjet och skapade en 'anti'-identitet bland en del av den ryska urbana medelklassen" (Lonkila 20I2, s. 6). En avgörande roll spelade den drastiska politiseringen av denna miljö och den regeringsfientliga masskampanj som blommade ut i sociala medier under hösten 20II (inberäknat kampanjen som uppmanade till att rösta på vilket parti som helst utom Enade Ryssland), oberoende av huruvida den hade koordinerats från ett eller flera centrum eller ej (Sachnin 20I4).

Som den ryska sociologen Maksim Aljukov skriver, var "den sista droppen, som till slut förvandlade diskussionerna i internetsfären till en offlineprotest, uppdykandet av en mängd videoklipp som visade polisens falsifikat och brutalitet i december 20II" (Aljukov 20I4). Enligt Aljukov framkallade de det som James Jasper kallar en "moralisk chock", det vill säga de känslor som dyker upp när en händelse eller information visar att världen inte är som den verkade vara, vilket leder till en reartikulering av de moraliska principerna och drar in människor i kollektivt handlande (Jasper 1997). ”Det som fick människorna som hade subjektiverats genom motoffentligheten att övergå till kollektivt handlande var den känsla av orättvisa som videoklippen om falsifikaten hade framkallat" (Aljukov 20I4).

Men mobiliseringsmodellen började förvandlas. De sociala mediernas informativa roll försvagades knappast, men koordinationsmekanismerna och just mobiliseringen började stödja sig på andra sociala mekanismer som hade tagit form inom själva rörelsen. Om en majoritet av demonstranterna gjorde sin första erfarenhet av kollektivt deltagande i samhällslivet i december 20II, så erkände 79 procent av respondenterna i Levadacentrets följande undersökning den 4 februari 2012 att de tidigare deltagit i någon dylik aktion eller till och med blivit engagerade i några fasta aktivistförbund. Aktivistförbunden växte utan tvekan parallellt med ett idémässigt sökande och ideologiskt-politiskt avgränsande. I motsvarande grad växte de mer eller mindre fasta aktivistnätverkens mobiliserande roll. 
Valobservatörsrörelsen antog en masskaraktär. Inte färre än 20000 personer genomgick en fortbildning arrangerad av två av de mest betydande organisationerna med denna profil - "Medborgare Bevakare" (Graždanin Nabljudatel') och sammanslutningen "Rösten" (Golos). En annan plattform där medborgaraktivisterna engagerade sig var "Protestateljén" (Masterskaja protesta). Initiativet till att skapa den togs av journalisten Masha Gessen. "Ateljéns" möten blev mycket snabbt regelbundna. En aktiviststomme formerades. Och den fungerade aktivt under drygt ett år. Gruppen Motstånd kan tjäna som ett annat exempel. Den hade från början varit en Facebookgrupp. Inom kort gick den dock offline och omvandlades till ett tämligen fast förbund. Gruppen specialiserade sig på att skapa föreställningar, agitationsutsändningar och en symbolik för rörelsen: pins, tygband, T-tröjor etc. De pengar man fick in gick till olika projekt som var kopplade till protesterna. Under det första halvåret i Bolotnajarörelsens utveckling uppstod och utvecklades framgångsrikt ett tiotal andra likartade initiativ, även om de flesta aldrig uppnådde en sådan grad av formalisering, medieframgång och inre strukturering.

Ett talande exempel var rörelsen "Vita bandet" (Belaja lenta). Detta förbund uppstod på basis av alldeles ytliga, symboliska aspekter. Det enda som förenade människorna var en vilja att på teckennivå, med vita band, demonstrera sitt missnöje med valfusket, och vidare med det som höll på att ske i landet. Men det stod snart klart att Vita bandet samtidigt existerade i två "inkarnationer". Å ena sidan som ett amorft och mycket brett förbund på internet (i första hand i sociala medier). I motsvarande grupper på Facebook och VKontakte var fler än Ioo ooo personer registrerade. Men detta enorma antal människor förvandlades inte alls till någon aktiviströrelse. Det mesta man kunde räkna med var deras sympatier. $\AA$ andra sidan formerades i Moskva en mindre grupp - om några tiotal aktivister - som framträdde å denna breda och partipolitiskt obundna rörelses vägnar. Dess företrädare var aktiva på ett stort antal möten, i organisationskommittéer, i Protestateljén, i Initiativgruppen för organiserande av protestmöten och så vidare. De framträdde på mötena, organiserade aktioner och gjorde uttalanden.

Även tidigare svagt politiserade aktivistförbund - de vänsterinriktade, liberalerna och nationalisterna - upplevde ett kolossalt tillflöde av 
aktivister. De anslöt sig också aktivt till agitations- och mobiliseringsarbetet. När vänstergrupperna deltog aktivt kom exempelvis "Folkorganisationskommittén" för den förestående "miljonmarschen" (demonstrationen den 6 maj) till Pusjkintorget i Moskva varje helg i mars-april 2012. Inga som helst anmälningar hade lämnats in till detta arrangemang, men uppslutningen var tämligen stor. Den 17 mars kom exempelvis omkring halvtannat tusen människor till torget. På de liknande möten som följde var det mindre folk, men likväl samlades några hundratal personer. ${ }^{3}$ Varje grupp formerade sitt eget nätverk, skapade telefonlistor där man inkluderade namnen på de aktivister och medborgare som åtminstone hade något slags koppling till organisationen. De "täta" aktivistnätverken växte fram kring de talrika kampanjer som tog sin början med försvararna av medlemmarna i gruppen Pussy Riot och försvararna av Cagovskijskogen i Zjukovskij nära Moskva (Sachnin 20I4). Dessutom upplevde en majoritet av aktivisterna i de lokala initiativen en tydlig koppling till den "stora" proteströrelsen.

Allteftersom aktivistnätverken utvecklades fick Facebookmobiliseringen träda tillbaka för aktivistmobiliseringen. Men bara på det fält där "offlinerörelserna" och de någotsånär strukturerade rörelserna verkade började kommunikationen "en till många" ersättas av modellen "många till många”. Och samtidigt inleddes en förändringsprocess av hela rörelsen. Betydelsen av det offentliga samtalet växte och dagordningen för den vidgades. Den ideologiskt-politiska avgränsningsprocessen intensifierades. Ledarnas kontroll över de reguljära deltagarna minskade.

Man kan säga att två mobiliseringsmodeller faktiskt samexisterade inom Bolotnajarörelsen - var och en kopplad till en viss verktygsuppsättning, men också till en särskild politisk kultur. Med visst förbehåll kan man kalla dessa modeller för, å ena sidan, den "populistiska" eller "mediala", och, å den andra sidan, den "aktivistiska” eller "demokratiska”. Men den kvalitativa skillnaden i föreliggande fall är inte kopplad till sociala nätverk och andra internetteknologier, utan till aktivistförbundens nivå av inre strukturering och egenorganisering.

3. Data hämtades från Vänsterfrontens hemsida (inte längre tillgänglig). 


\section{Den kollektiva identitetens sociala natur}

En spridd kliché som man tillämpar för att socialt karakterisera Bolotnajarörelsen (och beskriva andra sociala rörelser av denna art) är att förknippa den med medelklassen. Moskvas massproteströrelse begränsades dessutom till samhällets medelskikt redan innan denna protest hade hunnit utformas - i ett ryktbart föredrag från Centret för strategisk forskning (Centr strategičeskich razrabotok, CSR) av Sergej Belanovskij och Michail Dmitriev i mars 20II (Belanovskij \& Dmitriev 20II). De sociologer som blivit berömda genom sitt framgångsrika prognoserande av den politiska krisen fortsatte på temat om medelklassen och dess koppling till massprotesterna också i sina efterföljande forskningsarbeten (Centr strategičeskich razrabotok 20I2). Uppfattningen om Bolotnaja som en "medelklassrörelse" blev mainstream i sociologiska beskrivningar och den fick vid spridning i media och sociala nätverk.

Men denna föreställning lider inte bara av ett antal schematiska förenklingar. Bakom den står en annan - ideologiskt konstruerad - kollektiv identitet, som man tillskriver vissa värderingar, politiska inriktningar, strategier och praktiker. Massrundfrågningarna bland deltagarna i protestmötena 2OII-2OI2 vittnar om att deltagarsammansättningen, liksom de dominerande stämningarna och politiska sympatierna, genomgick en väsentlig förvandling. Den rundfrågning som genomfördes på Sacharovavenyn den 24 december 201 (det vill säga i själva början på proteströrelsen) gav exempelvis följande resultat. I jämförelse med de genomsnittliga indikatorerna för Ryssland och till och med för Moskva fanns det en betydligt större andel högutbildade unga, men också välbeställda medborgare, på Sacharovavenyn. Men företrädarna för den motsatta sociala polen - de fattiga - utgjorde också en förhållandevis stor del av de protesterande. Följaktligen stötte man på färre medelinkomsttagare bland dem än i genomsnittet i populationen. Till huvudsakliga yrkeskategorier visade sig 8 procent av Levadacentrets respondenter vara företagsägare och 17 procent företags- eller avdelningschefer. Praktiskt taget hälften av de tillfrågade identifierade sig själva som yrkesutbildade (46 procent), ytterligare 8 procent var kontorsarbetare, I2 procent studenter och vardera 4 procent industriarbetare eller biträden i butik eller inom tjänstesektorn. 
Av största intresse var fördelningen av respondenternas svar på frågan om politiska åsikter och värderingar (respondenterna kunde välja mer än ett alternativ). Det visade sig att de som själva kallade sig "demokrater" var allra flest -38 procent. På andra plats hamnade den liberala politiska identiteten - 3I procent. Tredje och fjärdeplatsen delades av anhängarna av vänsteråsikter - kommunister (I3 procent) och socialister (Io procent). 8 procent hänförde sig själva till "de gröna" (miljöaktivisterna). Nationalpatrioter visade sig allt som allt vara 6 procent och konservativa 3 procent. Vardera 2-3 procent kallade sig själva "nyvänster", anhängare av Antifa-rörelsen (bärare av vänsterradikala antiauktoritära värderingar) och anarkister. Summerat var det praktiskt taget samma mängd vänsteranhängare som liberaler. Demokraterna och miljöaktivisterna utgjorde rörelsens egenartade kärna. Nationalisterna och de dem närstående utgjorde en obetydlig högerflygel (9 procent).

Men allteftersom rörelsen utvecklades minskade andelen mer välbeställda medborgare (det vill säga just "medelklasskärnan") - de som kunde tillåta sig själv att köpa bil och andra kapitalvaror - från december 2011 till september 2012 från 33 procent till is procent. Av dem som deltog i demonstrationen den 15 september 20I2, ansågs 35 procent av proteströrelsens potentiella anhängare vara vänsteraktiva och kommunister, 34 procent "missbelåtna myndighetstjänstemän, arbetare och lantarbetare" och bara 23 procent stadens välbeställda skikt. Också andelen sådana som ansåg sig själva vara kommunister, socialister och nyvänsteraktivister växte - från $3 \mathrm{I}$ procent i december till 40 procent. Samtidigt sjönk antalet anhängare av liberala värderingar från 3I till 23 procent (Levada-Centr 2OII och 20I2). Allt detta vittnar om att det vore ett alltför djärvt antagande att entydigt koppla samman massprotesterna 2OII-2OI2 med medelklassens intressen och mobilisering. I maj 2012 skrev Michail Dmitriev och hans kollegor således att den av dem tidigare förutsedda tillväxten av den sociala antagonismen mellan medelklassen och "de andra masslagren" aldrig hade kommit till stånd. Tvärtom var "de prioriterade frågor där medelklassens och de andra masslagrens positioner sammanföll betydligt fler än de frågor där det uppstod motsättningar", vilket tillåter en "blandad" proteströrelse att utvecklas (Centr strategičeskich razrabotok 20I2). 
Man bör notera att ett av Bolotnajarörelsens viktigaste särdrag (och problem) var just den svaga kollektiva identitet eller - i mindre utsträckning - identiteter som deltagarna i proteströrelsen delade. I alla fall skapades aldrig något gemensamt språk för detta sociala intresse som de skulle ha kunnat använda. Detta blev bestämmande för målens suddighet, frånvaron av kompromisser och den allmänna förståelsen av rörelsens politiska och sociala uppgifter, deras allierade etc. Man kan likväl tala om något slags försök till social uppbyggnad av en kollektiv identitet som är tillämpbar på den ryska sociala rörelsen 20II-20I2. Men den vädjar inte till den ena eller andra socialgruppens erfarenhet och intressen (exempelvis medelklassens eller proletariatets), utan till demonstranternas egen omedelbart upplevda erfarenhet av kollektivt handlande. Nedan ska jag försöka visa att den kollektiva "Bolotnaja- och Sacharovidentiteten" uppkommit ur själva det faktum att aktivisterna varit fysiskt närvarande under samma protestaktion.

En produktiv analysmetod för denna problematik formulerades av författarna till antologin Politika apolitičnych. Graždanskie dviženija v Rossii 20II-20I3 godov ("De apolitiskas politik. Medborgarrörelsernas historia 2OII-2OI3"), av vilka en föreslog den lyckade termen "abstrakt kollektiv identitet" (Aljukov 20I4). I likhet med deltagarna i rörelsen Occupy Wall Street demonstrerade Bolotnajaaktivisterna det som man kan kalla för en "vi-är-här-identitet". Den visade sig i ett otal av massprotestmötenas populära paroller och slagordsrefränger av typen "Här är vi makten", "Vi har varit på Bolotnajatorget och kommer dit igen", och liknande. Som Oleg Žuravlev rättvist skriver handlade det inte så mycket om att "resa det ena eller andra kravet, som om kravet på erkännande" (Žuravlev 20I4).

Men vilka är dessa "vi"? För att svara på denna fråga bör man vända sig till den mycket djupa och varaktiga stigmatiseringsprocessen av det politiska som sådant i den ryska offentligheten och det ryska allmänna medvetandet. Denna fundamentala avpolitisering härrör från de passiva motståndspraktikerna mot den ryska maktkretsens auktoritära ideologiska anspråk, men också från den demokratiska rörelsens traumatiska erfarenhet av nederlag under perestrojkaepoken på 1990-talet (jfr Clément m.fl. 20Io). Inom ramarna för den politiska kultur som hade 
formerats i det moderna Ryssland blev avpolitiseringen i sin helhet inte bara en följd "av den framväxande politiska apatin, utan också av det pågående världarnas krig, vilket har resulterat i att privatlivet blivit det högsta goda, den sanna verkligheten, och offentligheten har förkastats och stigmatiserats" (Žuravlev 20I4). Men precis samma process förvandlades plötsligt från demobiliseringens huvudmekanism till sin raka motsats och började verka för mobilisering.

Eftersom den vuxit fram ur en mångårig erfarenhet av en apolitisk kultur, till och med stigmatisering av politik som en "smutsig hantering", kunde den oförutsedda mobiliseringen 20II-20I2 inte appellera till någon som helst form av det politiska, det vill säga till ideologier eller till klasser med sina sociala intressen och specifika former av kollektivt handlande. Bara en inspirationskälla återstod - själva mobiliseringserfarenheten, den tveklösa äktheten och det självklara värdet i den. Deltagarnas allra mest värdefulla erfarenhet var själva det faktum att de kollektivt deltagit i demonstrationerna. Alltså inte rörelsens innehållsaspekt utan dess formella sida. Men den tillmättes ett särskilt innehåll som ofta ställdes emot den politiska sfären som sådan: ärligheten, uppriktigheten, solidariteten. "Vi har varit på Bolotnajatorget och kommer dit igen", lovade slagordet för en av de mest massmobiliserande Facebookgrupperna med ett tiotusental medlemmar. Och det var verkligen många som kom till de följande protestmötena just för att reproducera och förlänga denna upplevelse av äkthet, uppriktighet och ärlighet som ställdes emot det korrumperade, egennyttiga och av lögner besudlade politiskt organiserade samhället (jfr Žuravlev i detta nummer).

"Vi-är-här-identitetens" triumf definierade verkligen ett av rörelsens grundproblem. Redan under sommaren och hösten 2012 började deltagarnas trötthet och desorientering framträda. I studien av demonstrationen den 15 september 20I2, som Levadacentret organiserade, framgick att deltagarna ansåg att proteströrelsens mest väsentliga svaghet låg i "frånvaron av ett tydligt handlingsprogram" (49 procent av svaren) (Levada-Centr 20I2). Men formerandet av ett sådant program var omöjligt just i kraft av frånvaron av en gemensam föreställning om de kollektiva intressen som proteströrelsen var kallad att försvara. De försök som olika ideologiska grupper gjorde för att dryfta detta dilemma, liksom 
experiment att formulera ett mer konkret politiskt och socialt program, bemöttes dessutom av många med fientlighet. Diskussioner och debatter inom den koalition som skapats uppfattades som ett hot. Sålunda intogs den tredje platsen i samma enkät av svaret att den grundläggande svagheten med rörelsen som isolerat fenomen låg i konflikterna mellan ledarna (29 procent).

Rörelsens kris och påföljande tillbakagång förutbestämdes av denna konflikt. Å ena sidan förmådde den hur som helst inte uppamma krafter att utveckla nya, mer komplexa och politiskt skarpskurna former av kollektiv identitet och socialt intresse. $\AA$ andra sidan ledde frånvaron av en innehållsrik agenda och en tydlig inriktning till att rörelsen snabbt urvattnades, till att man upprepade sig själv i det oändliga och i slutändan gick tillbaka. Folk blev trötta på upprepningarna av de bullriga men tomma slagord som ljöd från talartribunerna: "Här är det vi som är makten!”, ”Ryssland kommer att bli fritt!", och så vidare.

I rättvisans namn bör man säga att en del av proteströrelsens aktivister överskred den "abstrakta identitetens" gränser efter att ha antagit den ena eller andra formen av ideologisk rationalisering. I första hand berörde detta naturligtvis deltagarna i de politiserade grupperna och rörelserna och deras anhängare. Ett högst väsentligt steg i denna riktning togs under majmånadens "Occupyhändelser" när tusentals människor deltog i de diskussioner och seminarier som ägnades åt de sociala och politiska problem som landet stod inför, och dessa händelser konkretiserade under alla omständigheter deras positioner. Men detta förändrar inte att abstrakta former av kollektiv identitet dominerade bland majoriteten av deltagarna i rörelsen - även under dess mer framskridna utvecklingsstadium.

\section{"Tomhetsdiskursen" och ideologins "glömda" verktyg}

Skapandet av den "abstrakta kollektiva identiteten" skedde inte av sig själv. Rörelsen blev en kapplöpningsarena för olika ideologiska och diskursiva kulturer, politiska ideologier och värderingar. Och de hade naturligtvis sina bärare. Under 20II-20I2 fördes en hård kamp mellan de liberala politikerna och vänsteraktivisterna, vilka ingick i rörelsens organisatoriska strukturer, om huruvida man skulle inkludera sociala krav i 
protestmötenas agenda. Ur liberalernas synvinkel kunde detta splittra oppositionsfronten. Men vänsteraktivisterna ansåg att en oppositionsrörelse utan krav på sociala förändringar inte var till någon konkret nytta för de breda massorna och därför inte utgjorde något intresse för dem. Liberalerna gick med på att anta de sociala kraven först efter att vänsteraktivisterna hade ställt dem inför fullbordat faktum och proklamerat dem från protestmötets talarstol den I2 juni 2012.

Men problemet här är djupare än så. "Oppositionens enhetsfront" behövde inte bara offra de radikala kraven. Den knuffade på i riktning mot att avstå från en substantiell diskussion såvida den kunde "göra alla osams”. Man skapade ett tämligen primitivt diskursivt system som fortplantades genom sin inneboende tröghet och gjorde det omöjligt att formulera något som helst program vilket skulle ha kunnat överskrida de mest abstrakta kravens ramverk. Liberala politiker, som Boris Nemtsov, Vladimir Rysjkov och Aleksej Navalnyj, utnyttjade den personorienterade retoriken vilken kokade ner alla landets problem till Putins personlighet. Det var bara proteströrelsens radikala falanger som kritiserade de institutionella grundvalarna för det system som vuxit fram. Detta blev en av de orsaker som hindrade proteströrelsen från att i sina led inbegripa nya samhällsgrupper för vilka de sociala och ekonomiska problemen var viktigare än personkritiken mot landets president.

Men många av proteströrelsens ledare förde medvetet det offentliga samtalet på en nivå av allmän välvilja, eftersom detta gav dem ett maximalt manöverutrymme i deras kontakter med etablissemanget. Ingen ville ta på sig ansvaret för massornas "populistiska” krav, som, medvetet, var oacceptabla för de politiska eliterna. Dessutom kringgick denna populistiska retorik alla kontroversiella och substantiella frågor och stod i samklang med den politiska kultur som utmärkte bärarna av "vi-ärhär-ideologin". Under valkampanjen till oppositionens samordningsråd anordnades debatter mellan kandidaterna på tevekanalen Dozjd, under vilka de på 30 sekunder erbjöds att formulera sitt credo. De politiska uttalandenas begreppsklarhet blev naturligtvis rejält lidande. En av oppositionens mest populära politiker, Ilja Jasjin, tog sig exempelvis ur läget på följande sätt: "Vi förutsätter oss uppgiften att förnya landet" förklarade han - "genom en omfattande omstart av proteströrelsen och 
den ryska politiken. Vi vill helt enkelt öppna ett vädringsfönster och vädra ut landet" (Jasjin 20I2). Något program för att "vädra ut landet" diskuterades med avsikt aldrig. Sådana abstrakta deklarationer var en förutsägbar del av den populistiska "tomhetsdiskursen” som politikerna tog sin tillflykt till i sin strävan att utnyttja rörelsen i stället för att ta på sig något som helst ansvar.

För att vara rättvis måste man säga att det under Bolotnajarörelsens historia flera gånger gjordes försök att problematisera diskussionen mellan aktivisterna, ställa dem inför ett vitt spektrum av komplicerade uppgifter och blottlägga motsägelserna mellan många av ledarnas ställningstaganden. Det pågick exempelvis ett intensivt sökande efter en ny diskurs under majmånadens "Occupy Abaj”-händelser när man organiserade ett tiotal seminarier och föreläsningar i vilka tusentals aktivister deltog. På dem diskuterades de mest olikartade frågor: de politiska och sociala reformerna, fackföreningarna och de sociala rörelserna, samhällets kulturella problem, samverkan mellan aktivisterna och politikerna och demokratirörelsens utvecklingsvägar. Vänsterkrafterna försökte vid ett flertal tillfällen formulera ett långt bredare program för sociala reformer och hade även en viss framgång i detta.

Uppsättningen av allmänna slagord vilka nästan helt berövats konkret innehåll och vilka upprepades av talarna från talarstolen, var en av de mest allvarliga begränsningarna som hindrade rörelsen från att utvidgas, vilket i slutändan också ledde till att den slocknade. "Här är det vi som är makten!" var den refräng som ljöd på protestmötena och demonstrationerna. Men deltagarna i dem kände att denna trollformel inte gav några uttömmande svar på alla frågor om vad som skulle komma längre fram och vad man skulle företa sig för att landet skulle förändras.

De ideologiska grupperna försökte utnyttja rörelsen för att vidga sitt medlemsunderlag och för att försvara sina egna värderingar och föresatser. Detta retade en del av aktivisterna och deltagarna i rörelsen som i opposition mot detta upprättade demonstrativt avpolitiserade organisationsformer, exempelvis "Väljarligan" (Liga izbiratelej) eller Protestateljén. Men allteftersom de protesterande förlorade hoppet om möjligheter till kompromisser med makten, kom de allt starkare att sympatisera med mer djupgående och radikala reformer av samhället och med de rörel- 
ser med vilka de förknippade möjligheten till sådana förändringar. Det var detta som förklarade det växande intresset för de ideologiska grupperna, inklusive för sådana som föreslog mer radikala reformprogram för samhället.

Bolotnajarörelsens försök demonstrerar också närvaron av en potential att fördjupa och utvidga det offentliga samtalet och att få det att överskrida den tomma populismens begränsningar. I detta avseende verkar rörelsens vänsterfalangs historia vara ytterst betecknande. Som jag visat ovan var det just den som upplevde det allra största tillflödet av nya aktivister och en såväl kvantitativ som kvalitativ ökning av verksamheten. Demonstrationen den 6 maj 2012 blev en tveklös triumf när inte mindre än hälften av deltagarna i den enorma demonstrationen anslöt sig till vänsterkrafternas kolonner. Man föreställer sig att dessa framgångar var ett resultat just av att vänsteraktivisterna var bärare av det mest konkreta, substantiella och radikala programmet, men de strävade hela tiden också efter att fördjupa samtalet mellan deltagarna i rörelsen, något som de andra politiska falangerna, tvärtom, energiskt undvek. Men varken vänsterkrafterna eller nationalisterna lyckades bryta dödläget och förändra nivån och karaktären på den interna diskussionen inom rörelsen.

För de flesta av aktivisterna, som nu hade gjort sina första erfarenheter av kollektivt handlande, hade den ideologiska ståndpunkten redan från början formerats på en emotionell, ibland estetisk nivå ("Prochorov är sympatisk", exempelvis, eller "Jag gillar Vänsterfrontens flagga”). Därefter genomgick ståndpunkterna en skärpning i samklang med det ideologiska spektrumet, vars grundvalar man redan hade lagt. Med stöd i egna intryck från personlig bekantskap med aktivister av olika åsiktsschatteringar, med deras skiftande etiska och estetiska form, kunde en "nyfrälst" under loppet av bara ett par månader korsa hela det ideologiska spektrumet från ytterkant till ytterkant. Som regel sammanföll denna transformering med ett av de allra viktigaste vägskälen som rörelsen genomlevde i sin helhet. Detta kraftfulla tillföde av aktivister till vänsterrörelserna sammanföll med den tid, mellan mars och maj 20I2, när just de, inom ramarna för förberedelserna för "miljonmarschen", blev huvuddrivkraften i massproteströrelsens mobilisering. Och därefter 
följde en vågrörelse som kom att bli förknippad med just deras roll under "Occupyhändelserna" (Šubin \& Sachnin 2013).

Vilka otillförlitliga uppgifter de än stödde sig på så fanns det med andra ord ändå en politisk dimension i dessa transformationsprocesser. Bakom de "etiska" eller "estetiska" åsikterna doldes oftast en strategisk eller taktisk bedömning gjord av den ena eller andra politiska ledaren eller aktivistförbundet. Det politiska valet baserade sig alltså inte på rationella utan på "etiska" motiv, men därigenom upphör det inte att vara i grunden politiskt.

Ett flertal av de deltagare som hade definierat sig själva i ideologiska termer, efter att de hade dragits in i medborgarrörelsen, hade varken attraherats av den ena eller andra organisationen eller av teoretiskt inriktade argument. Det var olika aspekter av praktiken som hade förtrollat nästan alla av dem. När till exempel bara en av proteströrelsens alla ledare, Sergej Udaltsov, visade prov på politisk aktivitet efter presidentvalet, och de övriga på det ena eller andra sättet distanserade sig från gatumobiliseringarna, började väldigt många aktivister ansluta sig till Vänsterfronten (komma till sammankomster, delta i aktioner, ansöka om medlemskap), trots att de dittills aldrig hade bekänt sig till några vänsteråsikter.

Av den stora mängd intervjuer som gjordes med aktivisterna framgår att många av dem, mer eller mindre rationellt, var medvetna om att en kollektiv aktion, som deltagandet i en massdemonstration, bara är det första steget på vägen mot sociala förändringar. Fortsättningen borde ha varit att skapa organisationer, grupper, institutioner och andra beståndsdelar i proteströrelsens infrastruktur. Bolotnajarörelsen utarbetade en tydlig och tämligen stark efterfrågan på organiserade och ideologiskt grundade former och strukturer för åsiktsfränders kommunikation (organisationer, ideologiska grupper, diskussionsplattformar etc.). De var nödvändiga för en betydande del av aktivisterna, eftersom det var det enda sättet att formera en gemensam rationalisering och en tilltro till det riktiga i den väg man valt, och för att få till stånd en koordinering av aktionerna (Želnina 20I4). 


\section{Bolotnajarörelsen och eliterna}

Ett av de allra viktigaste dilemmana som Bolotnajarörelsen ställdes inför under loppet av hela sin historia var frågan om förbindelserna med etablissemanget eller deras konkreta företrädare. Frågan om hur man borde genomföra förändringar i landet diskuterades i nästan samma form som Aleksandr Herzen (ryska Gertsen) formulerat ett halvtannat århundrade tidigare: "med penna eller yxa" (Gertsen i860). Konflikterna inom den ryska elitens högre kretsar kom upp till ytan redan i början av massprotesterna. Under åren 2008-20II satte en betydande del av det ryska samhället (särskilt dess toppskikt) sitt hopp till en successiv liberalisering av det politiska systemet ovanifrån. Dessa förhoppningar var förknippade med presidenten Dmitrij Medvedev. I medierna och det politiserade segmentet av de sociala nätverken fördes en diskussion angående huruvida det var möjligt att skapa ett förbund mellan de "ideella samhällsaktörerna” och maktens liberala falang. Detta ämne var särskilt betydelsefullt för aktivisterna från och ledarna för den liberala oppositionen. Man diskuterade också möjligheten att skapa ett block eller förbund mellan den liberala delen av den härskande eliten och den liberala oppositionen mot Putin.

När Medvedev på det regerande partiet Enade Rysslands kongress 24 september 201 I föreslog att man skulle stödja Putins kandidatur i presidentvalet i mars 20I2, kom förhoppningarna om en liberalisering uppifrån på skam. Denna rockad pressade en del av samhället, i första hand i huvudstäderna, till en protestaktion som de tidigare inte övervägt. ${ }^{4}$ Efter den 24 september aktiverades maktkritiken drastiskt inom oppositionen och till och med i tidigare neutrala massmedier. I sociala medier inleddes en kampanj som inte bara var inriktad på regimkritik (sådan fanns det tillräckligt av redan tidigare), utan även på förberedelse för gatumobiliseringar och andra protesthandlingar. I de regeringstrogna publikationerna överdrevs frågan om denna kampanjs koordinationsgrad. Alldeles oavsett hur det var med den saken, måste man tillstå att denna kampanj till sina

4. I de intervjuer som jag samlat in med aktivisterna i rörelsen för rättvisa val finns en lagbundenhet: om folk med aktivisterfarenhet praktiskt taget inte alls reagerade på rockaden, och folk med vänsteråsikter eller nationalistiska åsikter bekymrades mycket lite av den, utnämnde personer med liberala övertygelser - liksom de mest moderata aktivisterna - den ofta till avgörande för deras beslut att övergå till aktiva protesthandlingar. 
essentiella aspekter har visat sig vara relevant för de stämningar som grep om sig i samhället, samt att den framkallat en livlig reaktion.

Michail Dmitrievs och Sergej Belanovskijs rapport "Det åldrande varumärket Putin" ("Starejuščij brend 'Putin"), som hade publicerats i den inflytelserika tidningen Vedomosti (med en image av megafon för storkapitalet) 9 november 20II, väckte stark politisk genklang. I denna fastslogs det att "det samlande politiska 'tandemvarumärket' som blivit ett resultat av rockaden har medfört irreparabla förluster", och "Tandemets rockad har försvagat utsikterna till att makten ska förändras av sig själv och möjligheterna att upprätta en dialog med samhället" (Dmitriev \& Belanovskij 20II). Om en dialog är omöjlig och makten är försvagad kan utövandet av påtryckningar på den bli den mest effektiva handlingen.

Än mer förvånande var att makten kritiserades inte bara av bloggare, experter och journalister, utan även av tidigare lojala företrädare för den politiska eliten. Några fall väckte särskilt gensvar. Aleksej Kudrin, vice premiärminister, en person som under mer än elva år hade lett det centrala finansdepartementet, och åtnjutit ett utomordentligt inflytande, uttalade sig offentligt i Washington. Han sade att han inte tänkte delta i arbetet i den framtida regeringen Medvedev, med vilken han, framkom det, hade "betydande åsiktsskiljaktigheter". Kudrin gjorde ingen hemlighet av att hans utträde hade framkallats av ett missnöje med rockaden. Han avskedades inom kort och förvandlades till en av den liberala frondens informella ledare. Ett uttalande i parlamentet från ledamoten från partiet Rättvisa Ryssland, Gennadij Gudkov (som tidigare innehaft höga poster inom KGB/FSB), i slutet av november $201 \mathrm{~m}$ blev en annan offentlig skandal. Han kritiserade Enade Ryssland i skarpa ordalag och presidentens administration för att förbereda omfattande valfusk inför det förestående valet och hotade direkt med gatuprotester.

Strax före massproteströrelsens inledning påbörjades alltså en energisk konsolidering av de missnöjda på samhällstrappans alla nivåer - i den mån missnöjet omfattade dem, gällde detta även i lägre utsträckning en del av de ryska toppskikten. På så vis splittrades samhället uppifrån och ner. Elitföreträdarnas inflytande på själva proteströrelsen förnams särskilt starkt under den inledande fasen, i december 20II-februari 2012. Denna fas blev förknippad med ett antal personer. 
För det första "trängde" den skandalösa oligarken Michail Prochorov sig "in" bland rörelsens offentliga ledare. Han kom till demonstrationerna och försökte till och med göra uttalanden från talarstolen, men lyckades på grund av motstånd från en del aktivister inte göra det. Eftersom Prochorov var kandidat i presidentvalet var Bolotnajarörelsen en ytterst värdefull publik och väljarbas för honom. Bland rörelsens ledare spreds överdrivna rykten och diskuterades idéer om att lyfta fram och positionera Prochorov som "kandidaten från Bolotnajatorget". Det var i synnerhet Nemtsov och Rysjkov som vände sig till Vänsterfronten med ett sådant förlag. Vänsteraktivisterna sade inte bara nej, utan utformade därtill ett block med Gennadij Ziuganov inför valet och omintetgjorde på så vis själva begreppet "samlingskandidat" (Sachnin 20I4) för proteströrelsen. Även några andra av storfinansens ledare, exempelvis Aleksandr Mamut, deklarerade offentligt sina sympatier för proteströrelsen.

För det andra spelade Aleksej Kudrin en ytterst viktig roll. Som personlig vän till Putin och under många år styresman för den ekonomiska politiken i landet, hade han icke desto mindre en utstrålning av ideologisk liberal och åtnjöt en enorm aktning bland företrädare för näringslivet, samt, delvis, en del av den statusbärande intelligentian. Kudrin framträdde på en av de största aktionerna i rörelsens historia - den 24 december 20II på Sacharovavenyn. Under sitt framträdande formulerade han konkreta idéer om demokratirörelsens strategi och taktik. Han uppfattade dialogen med makten och sökandet efter en kompromiss med den som en nyckeluppgift: "annars blir det revolution. Annars förlorar vi den chans som ligger framför oss i dag - till fredlig transformation och förtroende.” Därför föreslog Kudrin att man skulle skapa en grupp, "som förmår formulera de politiska reformkraven", och inleda förhandlingar med Putin eller hans representanter.

Den formel som Kudrin hade föreslagit stöddes av många inflytelserika politiker, affärsmän och intellektuella. Exempelvis Igor Jürgens, chef för tankesmedjan INSOR (det namn massmedierna gav Medvedevs "idébank")s:

5. "Institutet för samtida utveckling" (Institut sovremennogo razvitija), tankesmedja som står Medvedev nära. Övers. anm. 
Aleksej Kudrin erbjöd sig de facto att medla i dialogen mellan den rådande makten och dem som kom till den osystematiska oppositionens protestmöten [...] Kudrin förkastar revolutionen och driver "osystematikerna" mot idén om gradvisa förändringar. En enskild punkt i främjandet av sådana förändringar borde bli "arbetet med de maktpersoner som är progressiva pragmatiker", förklarade Jürgens i en intervju med tidningen Kommersant. Till dem hänför han den del av eliten som var inriktad på modernisering och därför inför september 20II satte sin tilltro till Medvedevs andra presidentperiod (Chamraev \& Bašlykova 2OII).

Även tevestjärnan Ksenija Sobčak, dotter till Putins tidigare chef, uttalade sig skarpt mot "revolutionsscenariot". "Det viktigaste är att påverka makten och inte att bekämpa den", förklarade hon från protestmötesscenen den 24 december. Men såväl Kudrin som Sobčak blev utvisslade av protestmötets deltagare. Detta tydde på att företrädarna för Putinetablissemanget och den kulturella eliten inte åtnjöt något stort förtroende hos demonstranterna.

Sammanbrottet för försöket att skapa en stabil kontrollmekanism för massproteströrelsen från den liberala delen av eliten, och på så vis instrumentalisera den, kan förklaras av de omfattande antielitära stämningarna bland deltagarna i protestaktionerna, liksom av det medvetna motståndet från vänsteraktivistorganisationerna (i första hand Vänsterfronten), och delar av de andra grupperna och rörelserna (inklusive, exempelvis, en majoritet av aktivisterna i Garri Kasparovs liberala Solidaritet).

Men en rad framträdande ledare stödde även fortsatt strategin inriktad på en instrumentalisering av massproteströrelsen och dess varaktiga allians med företrädarna för etablissemanget. Exempelvis framlade Dmitrij Gudkov i juni 2012 sin syn på oppositionens uppgifter i artikeln "Vad revolutionärerna vill" ("Čego chotjat revoljucionery") som publicerades i Vedomosti. I denna artikel beskrev han tillsammans med sina medförfattare den, i hans ögon, optimala strategin. "Oppositionen måste" - skrev han - "handla så att eliten börjar uppfatta deras krav som lockande erbjudanden" (Gudkov m.fl. 20I2). Till den ändan föreslog författarna att man skulle avstå från att diskutera de sociala och ekonomiska problemen, som bara skulle splittra oppositionen. Dessutom ansåg de att man borde ge den styrande eliten övertygande garantier om deras personliga säkerhet och deras egendoms okränkbarhet. De skrev: 
[I dag är de stora företagsägarna] i många avseenden konsoliderade kring regimen eftersom de fruktar en postrevolutionär omfördelning av egendomen och en omfattande granskning av tvivelaktiga ekonomiska praktiker från den föregående perioden. En betydande del av byråkratin på hög-och mellannivå som kan ha en inre beredskap att stödja politiska förändringar, stödjer också regimen av fruktan för omfattande antikorruptionsgranskningar. Om man kunde avlägsna liknande farhågor skulle många av dessa personer öppet kunna stödja oppositionen eller åtminstone kunna sabotera verkställandet av obehöriga anvisningar för den händelse att en politisk kris utvecklas.

\section{Och drog slutsatsen:}

I förbindelse med detta borde oppositionen, för att transformationen av det politiska systemet ska förlöpa oblodigt och evolutionärt, erkänna nödvändigheten av ett brett antagande av odemokratiska garantier för den regerande eliten (Gudkov m.fl. 20I2).

Gudkov och hans kollegor begrep att "förverkligandet av en dylik amnesti kommer att vara ytterst impopulär, särskilt i de radikala oppositionskretsarna". I sin artikel, som var adresserad till just företrädarna för den elit som den handlade om, skrev de därför rättframt: "Föreställ er att samhällsfördraget om nya regler för det politiska livet måste nå fram till såväl de moderata regeringsföreträdarna som till de moderata oppositionsföreträdarna." Bland de senare nämndes åter Aleksej Kudrins namn som en idealisk medlare i förhandlingarna mellan parterna (Gudkov m.fl. 20I2).

Den sista kraftinsatsen för att sluta en öppen allians med den "progressiva delen" av den putinska eliten gjordes, slutligen, under sommaren och hösten 2012 av Navalnyj och hans anhängare under förberedelserna och genomförandet av valet till oppositionens så kallade samordningsråd. Det var i synnerhet en av de framträdande oppositionella och den framtida grundaren av "Navalnyjpartiet" (Partija Navalnogo), Leonid Volkov, den före detta ordföranden för "De oppositionellas centrala valkommission", som i en intervju dagen efter valet rakt ut sade:

Splittringen av eliterna utmed denna linje är synlig för blotta ögat. Den måste intensifieras. Hur? [...] En hypotetisk situation där oppositionen kommer till makten tycks för affärslivet vara fullständigt obegriplig och oöverblickbar. De är faktiskt bildligt talat rädda för Udaltsov, bildligt talat för vänsterkrafterna och 
bildligt talat för idén om ett ryskt - meningslöst och obarmhärtigt - uppror, idén om att frånta och fördela, expropriering, ett brott mot det privata ägandets ordning etc., etc. [...] Om vi, grovt talat, kan visa att revolutionsscenariot också är begripligt, kan förutse att även det är bättre än det putinska scenariot, så kommer vi också därmed att formulera själva detta offentliga erbjudande till den liberalt inriktade delen av storfinansen, vilket kommer att framkalla en splittring av eliterna och situationen kommer snart att avslutas med en palatskupp [...] En ytterst viktig del av denna historia är valet till "Samordningsrådet för den ryska oppositionen", som vi just nu är sysselsatta med. ${ }^{6}$

På så vis såg ledaren för "centrala valkommissionen" sin huvuduppgift i att visa för storfinansen, och den liberalt inställda delen av den ryska eliten, att de moderata och "avtalsförmögna" krafterna var i stånd att inte låta Udaltsov och vänsterkrafterna "bildligt" utgå med segern. Och bara detta öppnade, i hans ögon, utsikter för förändringar i landet. Rörelsens roll i dessa utsikter begränsades av ett "hemligt revolutionärt massmöte" för den "progressiva" delen av eliten. Men de otaliga försöken att formulera ett "officiellt avtalserbjudande" mellan den demokratiska rörelsen och en del av regeringskretsarna gick om intet. I många avseenden på grund av att de mötte ett organiserat och medvetet motstånd från inflytelserika och populära krafter som hade deltagit i protesterna.

Vänsterkrafterna intog en principiellt antielitär ståndpunkt och deltog i skapandet av Medborgarkommittén (i början kallades den Initiativgruppen), vilken väsentligt begränsade de statusbärande politikernas möjlighet att manipulera rörelsen. Denna struktur pretenderade på kontrollfunktionen över de stora protestmötenas dagordning, inklusive talarlistorna. I maj 2012 blev vänsteraktivisterna lokomotiv för den ytterst egalitära "Occupyrörelsen", vars aktivister bestred legitimiteten i proteströrelsens egen styrelsemodell. I slutändan underströk Udaltsov och andra vänsteraktivister i sin retorik ständigt att rörelsens demokratiska potential var förknippad med kampen mot hela den postsovjetiska elit som hade vuxit fram ur det auktoritära och korrumperade politiska system som byggts upp under Jeltsin och Putin, och som baserade sin makt på de orättvisa resultaten av privatiseringarna under 1990-talet och

6. Intervju med Volkov som publicerades av YouTube-kanalen Srok (avsnitt I024) den 30 september 20I2, tillgänglig på https://www.youtube.com/watch?v=83j5vwIPKUw, hämtad den 23 december 2015 . 
hade intresse av en fortsättning på nyliberala reformer med auktoritära metoder.

Men det är viktigt att anmärka att det i den demokratiska koalitionen, jämte vänsteraktivister, även ingick andra starka aktivister och ledare som hade framträtt mot en allians med etablissemanget. Till dessa hörde till exempel liberalerna Garri Kasparov, Andrej Illarionov och Andrej Piontkovskij och nationalisten Vladimir Tor. Kasparov, Illarionov och Piontkovskij fördömde sålunda kategoriskt Navalnyjs och Nemtsovs försök att sluta ett formellt (om än inofficiellt) avtal med företrädarna för den ryska oligarki som anfördes av Michail Fridman, Anatolij Tjubajs, Alisjer Usmanov och Aleksandr Volosjin. Det var just de som publicerade informationen om dessa inflytelserika affärsmäns och politikers möte med några medlemmar i Samordningsrådet för den ryska oppositionen i december 2012 (Gnezdilov 20I3; Piontkovskij 2012). Även de ryska nationalister som deltagit i proteströrelsen talade ofta i sina offentliga framträdanden om sitt misstroende mot varje form av inofficiellt samarbete med den ena eller den andra grupperingen i den ryska eliten.

Misstroendet mot företrädarna för toppskikten var massivt. Människoskarorna på protestmötena visslade upprepade gånger ut de statusfyllda politikerna, oligarkerna och mediestjärnorna. Men de hade ändå ett stort antal anhängare. Och än fler var de som tyckte att företrädarna för "elitfronden" var ett mindre ont i jämförelse med Putinadministrationen. Utan medvetet och organiserat motstånd hade därför strategin att sluta ett avtal med den "progressiva" delen av eliten mycket stora utsikter att lyckas.

\section{Den aktivistiska och populistiska kulturen}

Allt detta sammantaget - kombinationen av mobiliseringsmodeller, aktiviströrelsens former av kollektiva identiteter, deras ideologiska sympatier, de dominerande diskursiva praktikerna och formerna för att innesluta rörelsen i en vidare sociala kontext (inklusive deras inbördes relation med makten och den sociala eliten) - definierar de dominerande formerna av politisk kultur. Det vill säga rörelsens "genetiska kod" - de centrala parametrarna och huvudsakliga begränsningarna för dess 
utveckling. Analysen av Bolotnajarörelsens historia tillåter oss att dra en slutsats om den relativt konfliktladdade samexistensen mellan två modeller av politisk kultur inom proteströrelsen: den populistiska och den aktivistiska. ${ }^{7}$

Man kan se de medielanserade "stjärnornas" och elitföreträdarnas "demokratiska populism" som den första stabila formen av organisatorisk politisk kultur i rörelsen. De statusladdade "demokraterna" styrde och ställde i talarstolarna och var beredda att leda den lydigt lyssnande massan, men större delen av deras verksamhet hade en inofficiell, undanskymd karaktär. En betydande del av deltagarna i Bolotnajarörelsen var på det klara med det problematiska i denna kultur, vilket till exempel återspeglades i de talrika ironiska kommentarerna om samarbetet mellan "hövdingarna" och "hamstrarna". ${ }^{8}$ Kulturen reproducerades spon-

7. I själva verket kan man också urskilja en tredje specifik typ av politisk kultur - den dissidentiska. Men denna form hade utarbetats av det ryska civilsamhället långt före proteströrelsens uppkomst 2OII-2OI2 och hade mycket liten koppling till denna. Därför uppehåller jag mig i denna artikel vid de två former av politisk kultur som präglat de sociala rörelser jag refererat till. Vad den dissidentiska subkulturen anbelangar karakteriseras den av ett radikalt avståndstagande från såväl makten och dess institutioner, som samhällets "konformistiska" majoritet. Ett sådant förhållningssätt är, exempelvis, karakteristiskt för "Andra Ryssland" (Drugaja Rossija), liksom för en del av liberalerna och vänsterkrafterna. Det reproduceras av aktivisterna genom kampanjer som genomförs under deras inflytande (t.ex. av deltagarna i Strategija-3I). Kulten av offerberedvilligheten och de politiska massmötenas konfrontationsaktioner svetsar samman radikalernas subkultur och ersätter för flertalet av dem frågan om ett konstruktivt program för rörelsen och andra av kampens mål. Så snart dylika frågor hade framträtt bland aktivisterna påbörjades deras avfall från rörelsen. Ett ytterst viktigt problem för aktivistgrupper med denna typ av organisatorisk och politisk kultur var den praktiska omöjligheten att vinna inflytande i de breda sociala rörelserna, vilka de kallade "opportunistiska" eller "konformistiska”. Ett klassiskt exempel på en sådan konflikt var Eduard Limonovs anhängares utträde ur rörelsen den Io december 2OII och deras fortsatta taktik. Det är uppenbart att dissidenternas politiska kultur lämnade försumbara spår i rörelsen just på grund av deras tendens att avskärma sig från rörelsens kultur.

8. Inom det politiserade segmentet av den ryska internetsfären uppstod en hel tradition runt att diskutera samarbetet mellan oppositionsledarna och deras fasta anhängare. Inom traditionens ramar utvecklades ett särskilt slags jargong. Om ledarna benämndes med det groteska ordet "hövding" (och ibland till och med "führer"), för att understryka deras auktoritarism, ambitioner och fåfänga, benämnde man nedsättande deras anhängarskara - som var redo att följa sina avgudabilders härskrin - med öknamnet "hamstrarna". 
tant i olika aktivistmiljöer, men i protesternas historia 20II-20I2 blev liberala politiker, från Navalnyj till Nemtsov, de huvudsakliga ledarna för den. Det rörde sig alltså om de ledare som hade tagit ledningen för rörelsen under den inledande och avslutande etappen av dess utveckling. Till fördelarna med denna modell hör dess relativa effektivitet när det rör sig om att praktiskt verkställa fattade beslut, men också vad gäller lättheten att mobilisera anhängarna. Men den populistiska modellen ledde till att rörelsens demokratiska potential vattnades ur. I förlängningen fanns det, förutom (övervägande abstrakta) slagord, inte längre någonting kvar som skiljde den från det system den var inriktad på att bekämpa.

Men Bolotnajarörelsen uppvisade också en potential till egenorganisering som man kan sätta i relation till den aktivistiska modellen av politisk kultur. Denna modell förutsätter ett kollektivt beslutsfattande, en relativ egalitarism och en dominans av horisontella band, en öppen diskussion, en svag artikulering av budskap på förhand och fastlagda formella relationer. Ytterligare ett fenomen som är karakteristiskt för den "aktivistiska" politiska kulturen är dess ytterst stora intresse för en essentiell diskussion och för att utarbeta handlingsprogram (samtidigt är den mycket benägen till ideologiska konflikter och meningsskiljaktigheter). Den deltagarorienterade aktivistmodellen är ytterst praktisk och bygger på samarbete inom ramarna för konkreta sociala projekt och kampanjer. Denna aktivistkultur tog sig tydligt uttryck i "Occupyrörelsens" heroiska bedrift i maj 20I2, men också i en hel rad andra aktivistiska förbunds och koalitioners verksamhet i proteströrelsen.

Bärarna av den populistiska politiska kulturen tar konsekvent till en ytterst abstrakt retorik och strävar efter att undvika en fördjupning av det offentliga samtalet. Det tvingar dem att undvika det sociala intressets språk och tala bara till det som snarare skulle kunna kallas för den "abstrakta kollektiva identiteten". Därför blir slutresultatet att de alltid gör anspråk på att företräda "alla normala människors" intressen i kampen mot ett uppenbart socialt ont i stil med "korruptionen", utan att någonsin konkretisera principerna för hur den ska bekämpas. Inom ramarna för den aktivistiska politiska kulturen är, tvärtom, diskussionen ytterst viktig, argumentens kraft att övertyga och formerandet av ratio- 
naliseringssystem. Därför ideologiseras förbund som fungerar på detta sätt relativt snabbt och intar sin plats i det politiska spektrumet.

Just konkurrensen mellan dessa två grundläggande principer för att organisera sociala rörelser - på intellektuell, strukturell och politisk nivå - blev också den allra viktigaste orsaken till proteströrelsens nederlag. Motståndet från massaktivisterna, och en del vänsterpolitiker och liberala och nationalistiska politiker, mot en uppgörelse bakom kulisserna med företrädare för oligarkerna och det politiska etablissemanget, gjorde det omöjligt att förverkliga ett "färgrevolutionsscenario" i vilket en palatsrevolution med stöd av en osjälvständig massa på gatorna hade kunnat äga rum. Utan stöd från de statusladdade politikerna och storfinansen skulle aktivistförbunden, å andra sidan, inte ha haft tid, erfarenhet och resurser för att reorganisera den demokratiska rörelsen enligt nya principer, ge den en fast struktur och berika den med ett distinkt program för sociala reformer och ett effektivt system för intern horisontell samordning.

\section{Avslutning}

Erfarenheten av Bolotnajarörelsen i Ryssland tolkas i dag i samhällsdebatten och av forskarsamfundet i ljuset av en annan massrörelse i det postsovjetiska området under 2013-20I4: den ukrainska Majdanrörelsen. Parallellerna mellan dessa båda sociopolitiska mobiliseringar gör sig alldeles osökt gällande. I såväl det ena som det andra fallet gick hundratusentals "vanliga människor" (jfr Onuch 20I4) ut på gatorna för att utmana auktoritära och korrumperade regimer vilka hade slagit in på en impopulär kurs. Båda rörelserna upplevde problem med de traditionella formerna av kollektiv identitet och präglades av en föregående avpolitisering av samhället. Såväl under Bolotnajarevolutionen i Ryssland som under revolten som blev känd som euromajdan i Ukraina visade sig tydligt bristen på stabila strukturer för en social egenorganisation (fackföreningar, sociala rörelser), frånvaron av ett distinkt program för sociala reformer och institutionella kanaler som kunde användas för att trycka på för att få demonstranternas krav uppfyllda (jfr Popova 20I4; Poltorakov 2015). 
Kopplingen mellan Bolotnajarörelsen och Majdan postulerades av aktivisterna själva och ledarna för den ukrainska proteströrelsen. En betydande del av de ryska aktivister och politiker som var kopplade till Bolotnajarörelsen tog på det ena eller andra sättet del i händelserna i Ukraina eller solidariserade sig med den ukrainska revolutionen. Statstelevisionen i Ryssland drog direkta paralleller mellan händelserna i Moskva 2OII-2OI2 och störtandet av regimen Janukovytj 20I4. Till och med de förundersökningsledare som jobbade med "Bolotnajafallet" förklarade för de politiska fångarna - vars skuld de själva knappast trodde på - att "om man inte hade arresterat er, så hade det gått som i Ukraina”. 9 Men oavsett de paralleller som spontant gör sig gällande kan man på goda grunder anse att det finns fundamentala skillnader mellan de två massproteströrelserna i de båda grannländerna.

Till skillnad från i Ukraina har regimen i Ryssland inte bara hållit sig kvar, utan även med våld kväst oppositionen och utsatt en del av proteströrelsens ledare och aktivister för repressalier. Och detta faktum förklaras inte av någon skillnad i den ideologiska självrepresentationen av proteströrelsen i Moskva och Kiev, inte av graden av radikalitet och beredvillighet att ta till våld, utan av de fundamentala skillnaderna i deras inre struktur. Bolotnajarörelsen förblev, trots en del inflytande från företrädare från affärskretsarna och det politiska etablissemanget, en antonym till dessa, men Majdanrörelsen grupperade sig redan från början kring den infrastruktur som skapats av landets politiska och ekonomiska elit. I detta avseende fann sig Bolotnajarörelsen berövad stödet från samhällets toppskikt, men bevarade å andra sidan sin demokratiska potential.

Till skillnad från i Ukraina, där oppositionspartierna bibehöll ett väsentligt inflytande och där det dessutom existerade populära, av makten oberoende medier (Dyczok 20I4), likviderade Putinregimen under många år praktiskt taget all oppositionspolitik och alla större oberoende mediekanaler. Och just detta gav de oberoende aktivistförbunden - som hade få statusfyllda konkurrenter - möjlighet att uppnå en exempellös framgång. Jag vill argumentera för att rötterna till de principiella

9. Om ett sådant samtal berättade Aleksej Gaskarov för mig i ett privat brev från fängelset. Han är en av de ryska antifascisternas ledare och fick fängelse i tre och ett halvt år i Bolotnajafallet. 
skillnaderna mellan de sociala rörelser som har skakat de allra mest skiftande länder i världen - från Hongkong till USA och från Egypten till Ryssland - bör sökas i just detta: i elitens roll för att skapa och utveckla proteströrelsen. I slutändan är det just det som blir definierande för den dominerande typen av politisk kultur, för de övervägande diskursiva praktikerna och ideologiska formerna, mobiliseringsteknikerna etc. Rörelsernas demokratiska potential, deras politiska och sociala program, deras interna organisationskaraktär och deras möjlighet till långsiktig framgång i kampen att demokratisera sina samhällen är i slutändan beroende av just dessa faktorer.

\section{Översättning: Pontus Lindgren}

\section{Referenser}

Aljukov, M. (20I4) "Ot publik k dviženiju: kontrapubličnye v rossijskom internetprostranstve pered protestom”, i S. V. Erpyleva och A. V. Magun (red.), Politika apolitičnych. Graždanskie dviženija v Rossii 20II-20I3 godov, Moskva: Novoe literaturnoe obozrenie.

Belanovskij, S. och Dmitriev, M. (20II) "Političeskij krizis v Rossii i vozmožnye mehanizmy ego razvitija", från Polit.Ru, 28 mars 201 .

URL: http://polit.ru/article/20II/03/28/20II/ (23 december 20I5)

Centr strategičeskich razrabotok (2012) Obščestvo i vlast’v uslovijah političeskogo krizisa. Doklad ekspertov CSI koitetu Graždanskih iniciativ, Moskva: Institut municipal'nogo upravlenija.

Chamraev, V. och Bašlykova, N. (20II) "Peregovorščik", Kommersant, 26 december $201 \mathrm{.}$ URL: http://www.kommersant.ru/doc/1846078 (23 december 20I5)

Clément, C., Mirjasova, O. och Demidov, A. (2010) Ot obyvatelej k aktivistam. Zaroždajuščiesja dviženija v sovremennoj Rossii, Moskva: Tri kvadrata.

Dmitriev, M. och Belanovskij, S. (20II) "Starejuščij brend 'Putin”, Vedomosti, 2977, 9 november 2011 .

URL: http://www.vedomosti.ru/opinion/articles/20II/II/og/peremena_mest_ slagaemyh\#/cut (23 december 2015)

Dyczok, M. (20I4) "Information wars: hegemony, counter-hegemony, propaganda, the use of force, and resistance", Russian Journal of Communication, 6: 173-176. DOI: https://doi.org/Io.I080/I94094I9.20I4.908694

Feldman, E. (2OI2) "6 maj. Marš Millionov zaveršilsja massovymi zaderžanijami i uličnoj vojnoj s policiej (Chronika sobytij, video, foto)", Novaja Gazeta, 6 maj 2012. URL: http://www.novayagazeta.ru/politics/52457.html (23 december 2015)

Gertsen, A. I. (I860) "Predislovie k pis'mu iz provincii", Kolokol, 64. 
Gnezdilov, A. (20I3) "Počemu raspadajutsja ob’edinitel'nye proekty oppozicionerov?", Smart Power Journal, 12 april 2013.

URL: http://smartpowerjournal.ru/gnezdilov-combination-of-reasonable-forces/ (23 december 20I5)

Gudkov, D., Nekrasov, D. och Voronkov, K. (20I2) "Čego chotjat revoljucionery", Vedomosti, 3130, 26 juni 2012.

URL: http://www.vedomosti.ru/opinion/articles/20I2/o6/26/chego_hotyat_ revolyucionery (23 december 2015)

Jasjin, I. (20I2) "Vybory KS: debaty na Dožde", från Jasjins blogg Yashin, 4 oktober 2012. URL: http://yashin.livejournal.com/II2I220.html (23 december 20I5)

Jasper, J. M. (1997) The art of moral protest, Chicago: University of Chicago Press.

Levada-Centr (20II) Opros na prospekte Sacharova 24 dekabrja, Analitičeskij centr Levada, 26 december $201 \mathrm{I}$.

URL: http://www.levada.ru/old/26-I2-20II/opros-na-prospekte-sakharova-24dekabrya (23 december 2015)

Levada-Centr (2012) Opros na marše millionov, Analitičeskij centr Levada, I7 september 2012.

URL: http://www.levada.ru/20I2/og/r7/opros-na-marshe-millionov-v-moskve-15sentyabrya/ (23 december 2015)

Lonkila, M. (2012) Russian protests on- and offline. The role of social media in the Moscow opposition demonstrations in December 20II, FIIA briefing paper nr 98. URL: http://www.fiia.fi/assets/publications/bp98.pdf (22 december 20I5)

Onuch, O. (20I4) "The Maidan, past and present: Orange Revolution (2004) and the EuroMaidan (2013-2014)", i D. Marples och F. V. Mills (red.), Euromaidan, New York: Columbia University Press.

Piontkovskij, A. (20I2) "Oppozicija kak biznes-proekt Michaila Fridmana", från Piontkovskijs blogg på Echo Moskvy, I9 december 2012. URL: http://echo.msk.ru/blog/piontkovsky_a/9724I2-echo/ (23 december 20I5)

Poltorakov, A. (2015) "The functional dynamic of Ukraine's 'Maidan', Russian Politics and Law, 53: 28-36.

DoI: https://doi.org/I0.1080/I06II940.2015.1053783

Popova, M. (2014) "Why the Orange Revolution was short and peaceful and Euromaidan long and violent", Problems of Post-Communism, 61: 64-70. URL: http://www.tandfonline.com/doi/abs/10.2753/PPCio75-82166ro6os (3 november 2016)

Sachnin, A. (20I4) Bolotnaja revoljucija, Moskva: Algoritm.

Soboleva, I. (2013) "Otličaetsja li elektorat Putina ot storonnikov opozicii?", Slon.Ru, 29 april 2013.

Sokolov, D. (20I2) "Ot Facebook-revoljucija do bunta", Vedomosti, 30I6, II januari 2012. URL: http://www.vedomosti.ru/opinion/articles/20I2/oI/II/nezavisimyj_sud_kak_ obschaya_cel (22 december 20I5)

Šubin, A. V. och Sachnin, A. V. (2013) Istoričeskij opyt Perestrojki i rossijskoe graždanskoe obščstvo v 20II-20I2, opubliserad analytisk rapport till ett INOP-forskningsprojekt. 
Želnina, A. (20I4) 'Ja v eto ne lezu': vosprijatie ličnogo i obščestvennogo sredi rossijskoj molodëži nakanune vyborov", i S. V. Erpyleva och A. V. Magun (red.), Politika apolitičnych. Graždanskie dviženija v Rossii 20II-20I3 godov, Moskva: Novoe literaturnoe obozrenie.

Žuravlev, O. (20I4) "Inercija postsovetskoj depolitizacii i politizacija 2OII-2OI2 godov", i S. V. Erpyleva och A. V. Magun (red.), Politika apolitičnych. Graždanskie dviženija $v$ Rossii 20II-20I3 godov, Moskva: Novoe literaturnoe obozrenie. 


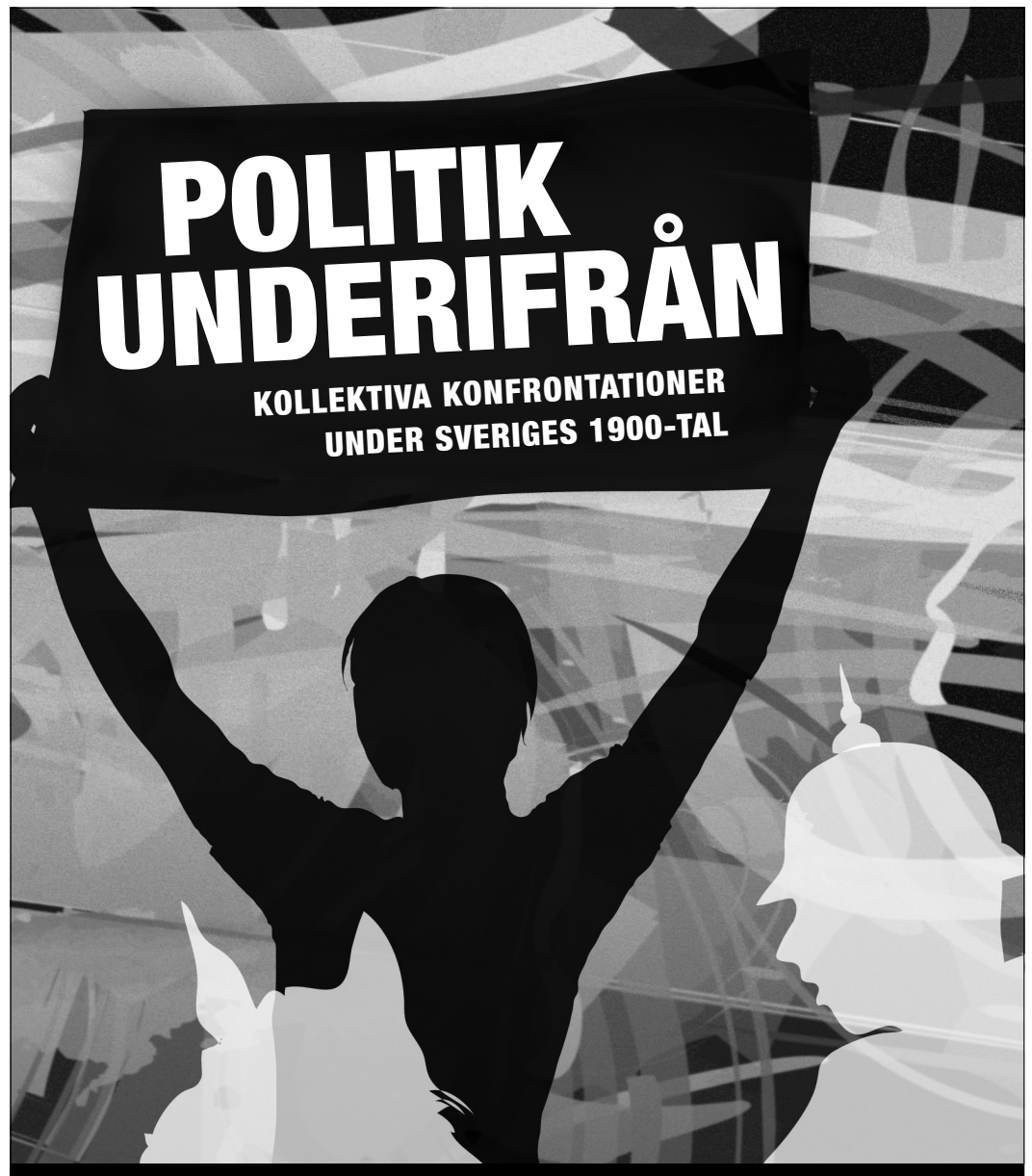

I POLIIK UWDERIFRÅN skriver historiker och samhällsvetare om politiska och sociala konflikter i 1900-talets Sverige då människor har brutit mot den dominerande politiska kulturens normer för hur man får göra politik och vilka som får delta i politiska processer. Från rösträttsstriden i början av seklet, över gatukravaller, vilda strejker och den gryende miljörörelsens kamp, till konflikter om vem som har rätt att använda det urbana rummet åren efter murens fall.

Andrés Brink Pinto \& Martin Ericsson (red.), Arkiv förlag, 216 sidor

\section{"LÄS MER OM BOKEN PÅ WWW-ARKIWWU:}

